\title{
IDENTIFIKASI RISIKO OLEH PENGEMBANG PERUMAHAN DI KOTA BANDA ACEH DAN KABUPATEN ACEH BESAR PADA MASA PANDEMI COVID-19
}

\author{
Khuzul Hidayat ${ }^{1}$ Nurul Malahayati ${ }^{2}$ Alfa Taras Bulba ${ }^{3}$ \\ ${ }^{1}$ Mahasiswa, Jurusan Teknik Sipil, Universitas Syiah Kuala, Banda Aceh 23111, Indonesia \\ ${ }^{23}$ Dosen, Jurusan Teknik Sipil, Universitas Syiah Kuala, Banda Aceh 23111, Indonesia \\ Email: Khuzul.hidayat@gmail.com
}

\begin{abstract}
Increased house construction by housing developers in the city of Banda Aceh and the District of Aceh Besar continious to show progress during the Corona Virus Disiase 2019 pandemic (covid-19) on cost losses, time losses, and decreased quality. Risks identification identified by 25 risk variables with Interview and questionnaire process by 4 housing developers. Amount of respondent in this study were 20 people from each company. Instrument testing used by validity test and reliability test. While data processing used by descriptive analysis and Frequency Index (FI) analysis assisted by Microsoft Excel software. The result of frequency index analysis show 5 domination risk variable that impact on cost losses, including house buyer candidates are pending to buying a house, Decreased selling house, additional cost for bringing worker from outside area, decreases demand housing, and less buyer interest. As many as 7 domination risk variable that impact on time losses including less advertising in the marketing it makes house sales are slow down, Resistance to material delivery, less material supply. As many as 1 domination risk variable that impact on decreased quality are less labor availability.
\end{abstract}

Keywords : risk identification, housing developer, potential risk of covid-19.

Abstrak

Peningkatan pembangunan rumah oleh pengembang perumahan di Kota Banda Aceh dan Kabupaten Aceh Besar terus mengalami kenaikan sebelum terjadinya bencana penyebaran pandemi Corona Virus Disease 2019 (COVID-19). Penelitian bertujuan untuk mengidentifikasi risiko-risiko yang dihadapi oleh pengembang perumahan semasa pandemi covid-19 terhadap kerugian biaya, kerugian waktu, dan menurunnya mutu. Teridentifikasi sebanyak 25 variabel risiko yang dilakukan melalui wawancara kepada 4 orang pengembang perumahan. Jumlah responden dalam penelitian ini sebanyak 20 orang pengembang yang akan mengisi kuisioner. Pengujian instrumen dilakukan dengan menggunakan uji validitas dan realibitas. Sedangkan pengolahan data dilakukan dengan analisis deskriptif, dan analisis frequency index (FI), yang dibantu dengan menggunakan software Microsoft Excel. Hasil analisis frekuensi indek menunjukan 5 variabel risiko dominan yang berdampak terhadap kerugian biaya diantaranya calon pembeli menunda pembelian rumah, penurunan penjualan perumahan, biaya tambahan untuk mendatangkan tenaga kerja dari luar daerah, penurunan permintaan rumah, dan minat pembeli kurang. Sebanyak 7 variabel risiko dominan yang berdampak terhadap kerugian waktu diantaranya kurangnya iklan dalam pemasaran sehingga memperlambat penjualan rumah, hambatan terhadap penyediaan material selama pembangunan rumah, keterlambatan pengiriman material ke lapangan, pemasok tidak dapat memenuhi pesanan material. Sebanyak 1 variabel risiko dominan yang berdampak terhadap menurunnya mutu yaitu ketersediaan tenaga kerja yang kurang.

Kata Kunci : identifikasi risiko, pengembang perumahan, risiko potensial covid-19. 


\section{Pendahuluan}

Noval [1] peningkatan pembangunan rumah oleh pengembang perumahan di Kota Banda Aceh dan Kabupaten Aceh Besar terus mengalami kenaikan sebelum terjadinya bencana penyebaran pandemi Corona Virus Disease 2019 (COVID-19). Kompas.com [2] permintaan rumah dari tahun $2015 \mathrm{~s} / \mathrm{d} 2019$ mengalami peningkatan $15 \%$ dan termasuk dalam golongan yang tinggi. Namun, pada masa pandemi Covid-19 ini penjualan rumah bersubsidi dan non-subsidi di Aceh mengalamai penurunan hingga $30 \%$. Penyebaran penyakit Covid-19 merupakan sebuah bencana lingkungan yang telah terjadi sejak Januari 2020 dan sampai sekarang.

Partamihardja [3] investasi pada sektor properti pada saat pandemi merupakan investasi padat modal yang mengandung risiko yang sangat tinggi. Sehingga bisnis properti harus mempertimbangkan pasar, sumber dana, pemasaran, serta mengambil keputusan berdasarkan prinsip security of investment. Risiko penyediaan produk perumahan bagi pengembang seperti halnya produk lainnya meliputi risiko keuangan, risiko teknis, risiko konstruksi, risiko manajemen, dan lain sebagainya. Manajemen risiko digunakan untuk menyeimbangkan dampak terhadap kerugian dan menghindari kesalahan.

Terdapat dua asosiasi perumahan yang aktif saat ini di Aceh yaitu Real Estat Indonesia (REI) dan Asosiasi Pengembang Perumahan dan Pemukiman Seluruh Indonesia (Apersi). Pengembang perumahan tersebut akan dihadapi oleh situasi ketidakpastian kondisi di lapangan yang merupakan konsekuensi risiko. Oleh karena itu risiko dan ketidakpastian harus dianalisis agar sasaran dapat dicapai.

Pada penelitian ini, yang menjadi objek lokasi penelitian adalah pengembang perumahan dan tergabung dalam asosiasi REI dan APERSI yang sedang melakukan pembangunan perumahan pada masa pandemi covid-19 di Kota Banda Aceh dan Kabupaten Aceh Besar.

Tujuan penelitian ini adalah untuk mengidentifikasikan risiko-risiko yang akan dihadapi oleh pengembang perumahan di Kota Banda Aceh dan Kabupaten Aceh Besar terhadap kerugian biaya, kerugian waktu, dan menurunnya mutu.
Penelitian ini dilatar belakangi dari hasil penelitian terdahulu tentang permasalahan yang diteliti yaitu manajemen risiko yang dialami pengembang perumahan yaitu : "Jarmias Tjakra, Freyke Sanggar, 2011 Analisis Risiko Pada Proyek Konstruksi Perumahan di Kota Manado" "Basuki Partamiharja, 2014 Persepsi Risiko Pengembang Perumahan di Kabupaten Bayumas" dan "Reyner, 2015 Analisis Risiko Pada Proyek

Konstruksi Perumahan di Kabupaten Minahasa Utara"

\section{Metodologi Penelitian}

\subsection{Objek dan Lokasi Penelitian}

Objek dan lokasi penelitian adalah pengembang perumahan yang sedang melaksanakan pembangunan rumah di Kota Banda Aceh dan Kabupaten Aceh Besar, yang merupakan perusahaan yang tergabung dalam asosiasi REI dan APERSI.

\subsection{Metode Pengumpulan Data}

Pada penelitian ini, data yang dikumpulkan terdiri dari data primer dan data sekunder. Data sekunder diperoleh dari 2 asosiasi yang terlibat dalam penelitian ini yaitu Real Estat Indonesia (REI) dan Asosiasi Pengembang Perumahan dan Pemukiman Seluruh Indonesia (Apersi). Data primer diperoleh dengan teknik wawancara dan penyebaran kusioener kepada responden. Adapun tahapan langkah-langkah pengumpulan data adalah sebagai berikut;

1. Identifikasi risiko dominan terjadi pada saat pembangunan perumahan pada masa pandemi covid-19 kepada responden yaitu 4 responden pengembang perumahan dari dari masing-masing perusahaan berbeda.

2. Setelah risiko dominan teridentifikasi maka dilakukan penyusunan form kuisioner yang akan disebarkan kepada 20 orang mewakili perusahaan pengembang perumahan.

\subsection{Metode Pengolahan Data}

Setelah seluruh data terkumpul, kemudian dilakukan pengolahan data. Adapun tahapan langkah-langkah pengumpulan data adalah sebagai berikut;

1. Rekapitulasi hasil pengisian data kuisioner.

2. Pengolahan data kuisioner dilakaukan dengan menguji valid dan reliabel dengan menggunakan uji validitas dan uji reliabilitas kuisioner. Pengujian validitas dilakukan terhadap 10 sampel responden 
dari masing-masing perusahaan berbeda sebagai tahap awal untuk mendapatkan hasil yang berupa variabel pertanyaan valid dan variabel pertanyaan tidak valid, setelah didapatkan hasil variabel pertanyaan yang tidak valid akan dieliminasi. Selanjutnya dilakukan tahap II terhadap 20 responden lanjutan tahap awal. Pengujian reliabilitas dilakukan untuk menguji layak atau tidaknya kuisioner yang telah disusun yang akan digunakan sebagai alat untuk mencapai tujuan penelitian ini berdasarkan nilai Cronbach Alpha> 0.6. Adapun persamaannya adalah sebagai berikut :

rhitung $=\frac{n\left(\sum x y\right)-\sum x \sum y}{\sqrt{\left(n\left(\sum x i\right)^{2}-\left(\sum x i\right)^{2}\right)\left(n\left(\sum y i\right)^{2}-\left(\sum y i\right)^{2}\right)}}(2.1)$

Keterangan :

$\mathrm{R}_{\mathrm{xy}}=$ Koefesien Korelasi

$\sum x=$ Jumlah Skor Item

$\sum x=$ Jumlah Skor Total (seluruh item); dan

$n$ = Jumlah Responden

$r=\frac{k}{(k-1)}\left[1-\frac{\sigma^{2} b}{\sigma^{2} 1}\right]$

Kererangan :

$\mathrm{r} \quad=$ reabilitas instrument;

$\mathrm{k}$ = banyaknya butir pertanyaan;

$\sigma^{2} b=$ varian butir; dan

$\sigma^{2} 1=$ varian total.

$\sigma^{2} b=\frac{J K i}{n}-\frac{J K s}{n^{2}}$

$\sigma^{2} 1=\frac{\sum x i}{n}-\frac{\sum x i^{2}}{n^{2}}$

Keterangan:

$\sum x i=$ jumlah total jawaban responden $\sum x i^{2}=$ kuadrat total jawaban responden

$\mathrm{JKi}=$ jumlah kuadrat seluruh butir

$\mathrm{JKs}=$ jumlah kuadrat subjek

3. Selanjutnya dilakukan analisis statistik deskriptif untuk mendapatkan nilai mean frekuensi terjadinya risiko berdasarkan jawaban responden. Adapun persamaannya adalah sebagai berikut :

$X=\frac{\mathrm{Xi}}{\mathrm{n}} \quad(2.5)$

Keterangan:

$\mathrm{X}=$ rata-rata

$\mathrm{Xi}=$ data yang diambil

$\mathrm{n}=$ jumlah data
4. Setelah itu dilakukan analisis frekuensi Indeks (FI) untuk menujukan indeks kemungkinan dan peringkat kejadian dari masing-masing variable risiko. Adapun persamaannya adalah sebagai berikut :

$F I=\frac{\sum_{i=1}^{5} a_{i} n_{i}}{N}$

Keterangan :

$\mathrm{i}=$ indeks katagori respons $(1,2,3,4$, dan 5)

$\mathrm{a}_{\mathrm{i}}=$ bobot yang dihubungkan dengan nilai

respons ke-i $(1,2,3,4,5)$

$\mathrm{n}=$ jumlah total responden

\section{Hasil dan Pembahasan}

\subsection{Hasil}

Hasil dari penelitian ini didapatkan dari hasil pengumpulan dan pengolahan data. Pengumpulan data dilakukan selama 2 bulan berupa jawaban responden terhadap identifikasi risiko yang dialami pengembang perumahan.

\subsubsection{Analisis Situasi}

Penelitian ini dilakukan di Kota Banda Aceh dan Kabupaten Aceh Besar yang terdiri dari pengembang perumahan dan tergabung dalam asosiasi REI dan APERSI yang sedang melakukan pembangunan perumahan pada masa pandemi covid-19.

\subsubsection{Karakteristik Responden}

Hasil wawancara dan kuisioner identifakasi variabel risiko dan penentuan pertanyaan kuisioner terhadap 4 orang responden yang mewakili perusahaan pengembang perumahan yang berbeda dapat dilihat pada Tabel 4.1.

Tabel 3.1 Karakteristik Responden Identifikas Risiko dan Wawancara

\begin{tabular}{l|lll}
\hline Pertanyaan & Katagori & Jumlah & Persentase \\
\hline \multirow{2}{*}{$\begin{array}{l}\text { Jabatan } \\
\text { Responden }\end{array}$} & Direktur & 2 & $50 \%$ \\
\cline { 2 - 4 } & Lain-lain & 2 & $50 \%$ \\
\hline \multirow{2}{*}{$\begin{array}{l}\text { Kenis } \\
\text { Kelamin }\end{array}$} & Pria & 3 & $75 \%$ \\
\cline { 2 - 4 } & Wanita & 1 & $25 \%$ \\
\hline \multirow{3}{*}{ Umur } & $20-30$ tahun & 1 & $25 \%$ \\
\cline { 2 - 4 } & $>30$ tahun & 3 & $75 \%$ \\
\hline \multirow{3}{*}{$\begin{array}{l}\text { Pendidikan } \\
\text { Terakhir }\end{array}$} & DIPLOMA & 0 & $0 \%$ \\
\cline { 2 - 4 } & SARJANA (S1) & 4 & $100 \%$ \\
\cline { 2 - 4 } & Pasca Sarjana (S2) & 0 & $0 \%$ \\
\hline \multirow{3}{*}{$\begin{array}{l}\text { Pengalaman } \\
\text { Kerja }\end{array}$} & $0-2$ tahun & 1 & $25 \%$ \\
\cline { 2 - 4 } & 2-4 tahun & 3 & $75 \%$ \\
\cline { 2 - 4 } & 4-7 tahun & 0 & $0 \%$ \\
\hline
\end{tabular}


ISSN 2685-0605

Karakteristik responden yang didapatkan dari hasil penyebaran kuisioner risiko terhadap 20 orang responden yang mewakili perusahaan pengembang perumahan yang berbeda dapat dilihat pada Tabel 3.2.

Tabel 3.2 Karakteristik Responden Kuisioner

\begin{tabular}{|c|c|c|c|}
\hline Pertanyaan & Data Responden & Jumlah & Persentase \\
\hline \multirow{3}{*}{$\begin{array}{l}\text { Jabatan } \\
\text { Responden }\end{array}$} & Direktur & 8 & $40 \%$ \\
\hline & Manager & 0 & $0 \%$ \\
\hline & Lain-lain & 12 & $60 \%$ \\
\hline \multirow{2}{*}{ Jenis Kelamin } & Pria & 19 & $95 \%$ \\
\hline & Wanita & 1 & $5 \%$ \\
\hline \multirow{3}{*}{ Umur } & $<20$ tahun & 0 & $0 \%$ \\
\hline & 20-30 tahun & 5 & $25 \%$ \\
\hline & $>30$ tahun & 15 & $75 \%$ \\
\hline \multirow{5}{*}{$\begin{array}{l}\text { Pendidikan } \\
\text { Terakhir }\end{array}$} & SD & 0 & $0 \%$ \\
\hline & SMP & 0 & $0 \%$ \\
\hline & DIPLOMA & 7 & $35 \%$ \\
\hline & SARJANA (S1) & 13 & $65 \%$ \\
\hline & Pasca Sarjana (S2) & 0 & $0 \%$ \\
\hline \multirow{4}{*}{$\begin{array}{l}\text { Pengalaman } \\
\text { Perusahaan di } \\
\text { Bidang } \\
\text { Konstruksi }\end{array}$} & $0-5$ tahun & 13 & $65 \%$ \\
\hline & 6-10 tahun & 7 & $35 \%$ \\
\hline & 10-15 tahun & 0 & $0 \%$ \\
\hline & $>15$ tahun & 0 & $0 \%$ \\
\hline \multirow{4}{*}{$\begin{array}{l}\text { Jumlah } \\
\text { Proyek } \\
\text { perumahan } \\
\text { yang Pernah } \\
\text { Ditanggani }\end{array}$} & $1-3$ & 12 & $60 \%$ \\
\hline & $3-6$ & 8 & $40 \%$ \\
\hline & $7-10$ & 0 & $0 \%$ \\
\hline & $>10$ & 0 & $0 \%$ \\
\hline \multirow{4}{*}{$\begin{array}{l}\text { Jumlah rumah } \\
\text { yang dibangun } \\
\text { pada masa } \\
\text { Covid-19 }\end{array}$} & $1-10$ & 3 & $15 \%$ \\
\hline & $10-20$ & 12 & $60 \%$ \\
\hline & $20-30$ & 4 & $20 \%$ \\
\hline & $>50$ & 1 & $5 \%$ \\
\hline
\end{tabular}

\subsubsection{Identifikasi Risiko}

Identifikasi risiko adalah langkah yang paling awal dari penelitian ini yaitu mengumpulkan variable-variabel risiko dengan faktor keuangan, penjualan dan faktor teknis lapangan dari referensi-referensi dan penelitian yang terdahulu. Metode yang digunakan untuk pengumpulan data ini adalah teknik checklist.

Tabel 3.3 Rekapitulasi identifikasi variabel faktor-faktor risiko $(1 / 2)$

\begin{tabular}{lll}
\hline \multirow{2}{*}{ No } & Faktor-faktor/variabel risiko & $\begin{array}{l}\text { Persentase } \\
(\%)\end{array}$ \\
\cline { 2 - 3 } & A. Faktor keuangan & $25 \%$ \\
\hline 1 & Menurunnya produktivitas pengembang & $100 \%$ \\
\hline 2 & $\begin{array}{l}\text { Calon pembeli menunda pembelian } \\
\text { rumah }\end{array}$ & $100 \%$ \\
\hline 3 & Penurunan penjualan perumahan & $100 \%$ \\
\hline 4 & Penurunan permintaan rumah & $75 \%$ \\
\hline 5 & Harga material naik & $25 \%$ \\
\hline 6 & Upah tenaga kerja naik \\
\hline
\end{tabular}

\begin{tabular}{lll}
\hline 7 & Desain kurang menarik & $0 \%$ \\
\hline 8 & Harga jual produk turun & $50 \%$ \\
\hline 9 & Lokasi terhadap pasar kurang sesuai & $0 \%$ \\
10 & $\begin{array}{l}\text { Kurangnya iklan dalam pemasaran } \\
\text { sehingga }\end{array}$ & $75 \%$ \\
\hline 11 & Belum ada pemasaran secara digital & $0 \%$ \\
\hline 12 & Persaingan pengembang & $25 \%$ \\
\hline
\end{tabular}

Tabel 3.4 Rekapitulasi identifikasi variabel faktor-faktor risiko $(2 / 2)$

\begin{tabular}{|c|c|c|}
\hline No. & Faktor-faktor/variabel risiko & Persentase \\
\hline & C. Faktor teknis lapangan & \\
\hline & 1. Faktor pelaksanaan lapangan & \\
\hline 13 & $\begin{array}{l}\text { Metode pelaksanaan konstruksi yang } \\
\text { tidak tepat sehingga menimbulkan } \\
\text { kesalahan selama pelaksanaan }\end{array}$ & $25 \%$ \\
\hline 14 & $\begin{array}{l}\text { Hambatan terhadap penyediaan material } \\
\text { selama pembangunan rumah }\end{array}$ & $100 \%$ \\
\hline 15 & $\begin{array}{l}\text { Kualitas pekerjaan kontraktor jelek atau } \\
\text { tidak sesuai SOP }\end{array}$ & $0 \%$ \\
\hline \multirow[t]{2}{*}{16} & Keterlambatan penyediaan utilitas & $75 \%$ \\
\hline & 2. Faktor tenaga kerja & \\
\hline 17 & $\begin{array}{l}\text { Kemampuan/skill tenaga kerja yang } \\
\text { kurang }\end{array}$ & $0 \%$ \\
\hline 18 & Ketersediaan tenaga kerja yang kurang & $75 \%$ \\
\hline 19 & Tenaga kerja mogok kerja & $0 \%$ \\
\hline 20 & Kecelakaan tenaga kerja & $25 \%$ \\
\hline \multirow[t]{2}{*}{21} & Perselisihan antara tenaga kerja & $50 \%$ \\
\hline & 3. Faktor material & \\
\hline 22 & Terjadinya pencurian material & $0 \%$ \\
\hline 23 & Kualitas material tidak sesuai spesifikasi & $0 \%$ \\
\hline 24 & $\begin{array}{l}\text { Keterlambatan pengiriman material ke } \\
\text { lapangan }\end{array}$ & $100 \%$ \\
\hline 25 & Penggunaan material bekas & $0 \%$ \\
\hline 26 & $\begin{array}{l}\text { Pemasok tidak dapat memenuhi pesanan } \\
\text { material }\end{array}$ & $100 \%$ \\
\hline \multirow[t]{2}{*}{27} & perubahan kebutuhan material & $50 \%$ \\
\hline & 4. Faktor politik \& legalitas & \\
\hline 28 & Perubahan kebijakan pemerintah & $25 \%$ \\
\hline 29 & Keterlambatan pembayaran oleh bank & $0 \%$ \\
\hline 30 & Keterlambatan ijin & $50 \%$ \\
\hline \multirow[t]{2}{*}{31} & Perselisihan kontrak konsumen & $0 \%$ \\
\hline & 5. Faktor alam & \\
\hline 32 & $\begin{array}{l}\text { Bencana alam seperti longsor, gempa } \\
\text { wabah penyakit sehingga menghambat } \\
\text { proses pembangunan rumah }\end{array}$ & $50 \%$ \\
\hline 33 & $\begin{array}{l}\text { Cuaca buruk sehingga pekerjaan } \\
\text { melambat seperti sering terjadi hujan } \\
\text { sehingga pekerja sering terganggu }\end{array}$ & $100 \%$ \\
\hline 34 & $\begin{array}{l}\text { Kebakaran yang mempengaruhi proses } \\
\text { berjalannya pembangunan }\end{array}$ & $0 \%$ \\
\hline 35 & Pencemaran Lingkungan & $0 \%$ \\
\hline 36 & $\begin{array}{l}\text { Adanya perubahan peraturan sehingga } \\
\text { proyek berhenti harus menyesuaikan } \\
\text { degan kebijakan atau peraturan baru }\end{array}$ & $0 \%$ \\
\hline 37 & $\begin{array}{l}\text { Berdasarkan protokol yang diterapkan } \\
\text { pemerintah terjadi hambatan selama } \\
\text { pelaksanaan pekerjaan di lapangan. }\end{array}$ & $75 \%$ \\
\hline
\end{tabular}

Berdasarkan table 3 hasil wawancara dan penyebaran kuisioner identifikasi variabel risiko didapatkan berupa dari 37 pertanyaan yang diajukan peneliti 25 variabel risiko yang teridentifikasi dan berdampak terhadap kerugian biaya, kerugian waktu, dan menurunnya mutu. Setelah variabel risiko yang teridentifikasi 
selanjutnya penyusunan kuisioner dilakukan. Kuisioner yang sudah tersusun akan disebarkan ke 20 orang responden mewakili dari masing-masing perusahaan pengembang perumahan yang berbeda. Setelah dilakukan penyebaran kuisioner dilakukan pengolahan data kuisioner dengan menguji variabel pertanyaan menggunakan uji validitas dan uji reliabilitas kuisioner.

\subsubsection{Uji Validitas}

Uji validitas tahap 1 pada penelitian ini dilakukan dengan mengambil 10 sampel responden dari masing-masing perusahaan yang berbeda, sehingga nilai $r$ tabel untuk taraf signifikan 5\% diperoleh sebesar 0.632. Sedangkan uji validitas tahap 2 dilakukan dengan mengambil 10 sampel responden, sehingga nilai $r$ tabel untuk taraf signifikan 5\% diperoleh sebesar 0.444.

Tabel 3.5. Rekapitulasi Hasil Uji Validitas Tahap 1

\begin{tabular}{|c|c|c|c|c|}
\hline No. & Kode & Rhitung & Rtabel & Keterangan \\
\hline 1 & $\mathrm{P} 1$ & 0.640 & 0.632 & VALID \\
\hline 2 & $\mathrm{P} 2$ & 0.912 & 0.632 & VALID \\
\hline 3 & P3 & 0.643 & 0.632 & VALID \\
\hline 4 & $\mathrm{P} 4$ & 0.606 & 0.632 & TIDAK VALID \\
\hline 5 & P5 & 0.596 & 0.632 & TIDAK VALID \\
\hline 6 & P6 & 0.505 & 0.632 & TIDAK VALID \\
\hline 7 & P7 & 0.902 & 0.632 & VALID \\
\hline 8 & P8 & 0.631 & 0.632 & TIDAK VALID \\
\hline 9 & P9 & 0.523 & 0.632 & TIDAK VALID \\
\hline 10 & $\mathrm{P} 10$ & 0.789 & 0.632 & VALID \\
\hline 11 & P11 & 0.648 & 0.632 & VALID \\
\hline 12 & P12 & 0.913 & 0.632 & VALID \\
\hline 13 & P13 & 0.657 & 0.632 & VALID \\
\hline 14 & P14 & 0.865 & 0.632 & VALID \\
\hline 15 & P15 & 0.725 & 0.632 & VALID \\
\hline 16 & P16 & 0.696 & 0.632 & VALID \\
\hline 17 & P17 & 0.835 & 0.632 & VALID \\
\hline 18 & P18 & 0.693 & 0.632 & VALID \\
\hline 19 & P19 & 0.692 & 0.632 & VALID \\
\hline 20 & $\mathrm{P} 20$ & 0.906 & 0.632 & VALID \\
\hline 21 & P21 & 0.803 & 0.632 & VALID \\
\hline 22 & P22 & 0.701 & 0.632 & VALID \\
\hline 23 & P23 & 0.640 & 0.632 & VALID \\
\hline 24 & P24 & 0.633 & 0.632 & VALID \\
\hline 25 & P25 & 0.888 & 0.632 & VALID \\
\hline 26 & P26 & 0.926 & 0.632 & VALID \\
\hline 27 & P27 & 0.733 & 0.632 & VALID \\
\hline
\end{tabular}

Berdasarkan tabel 4 dengan jumlah orang responden pengembang perumahan tahap awal yang di wawancara berjumlah 10 orang mewakili dari perusahaan pengembang perumahan yang berbeda dapat disimpulkan bahwa 5 variabel risiko dinyatakan tidak valid merupakan variabel dengan kode pertanyaan P4, P5, P6, P8, dan P9 sehingga variabel-variabel tersebut dieliminasi.

Tabel 3.6 Rekapitulasi Hasil Uji Validitas Tahap II (1/2)

\begin{tabular}{lllll}
\hline No. & Kode & Rhitung & Rtabel & Keterangan \\
\hline 1 & P1 & 0.558 & 0.444 & VALID \\
\hline 2 & P2 & 0.794 & 0.444 & VALID \\
\hline 3 & P3 & 0.610 & 0.444 & VALID \\
\hline 4 & P7 & 0.802 & 0.444 & VALID \\
\hline 5 & P10 & 0.661 & 0.444 & VALID \\
\hline 6 & P11 & 0.589 & 0.444 & VALID \\
\hline 7 & P12 & 0.806 & 0.444 & VALID \\
\hline 8 & P13 & 0.617 & 0.444 & VALID \\
\hline 9 & P14 & 0.801 & 0.444 & VALID \\
\hline 10 & P15 & 0.640 & 0.444 & VALID \\
\hline 11 & P16 & 0.528 & 0.444 & VALID \\
\hline 12 & P17 & 0.777 & 0.444 & VALID \\
\hline 13 & P18 & 0.646 & 0.444 & VALID \\
\hline
\end{tabular}

Tabel 3.6 Rekapitulasi Hasil Uji Validitas Tahap II (2/2)

\begin{tabular}{lllll}
\hline No. & Kode & Rhitung & Rtabel & Keterangan \\
\hline 14 & P19 & 0.607 & 0.444 & VALID \\
\hline 15 & P20 & 0.888 & 0.444 & VALID \\
\hline 16 & P21 & 0.734 & 0.444 & VALID \\
\hline 17 & P22 & 0.613 & 0.444 & VALID \\
\hline 18 & P23 & 0.592 & 0.444 & VALID \\
\hline 19 & P24 & 0.562 & 0.444 & VALID \\
\hline 20 & P25 & 0.828 & 0.444 & VALID \\
\hline 22 & P26 & 0.902 & 0.444 & VALID \\
\hline
\end{tabular}

Berdasarkan tabel 4.6 di atas dengan jumlah responden pengembang perumahan tahap 2 yang di wawancara berjumlah 20 oreng lanjutan dari tahap 1 dapat disimpulkan berdasarkan hasil pengolahan data bahwa semua variabel risiko dinyatakan valid, sehingga dapat dilanjutkan ke proses analisis selanjutnya.

\subsubsection{Uji Reliabilitas}

Berdasarkan hasil pengujian reliabilitas hasil yang didapatkan berupa keseluruhan variabel risiko pertanyaan pada kuisioner menunjukan tangkat ukuran kemantapan yang didapatkan berupa sangat reliabel.

\subsubsection{Analisis Deskriptif}

Tabel 3.8 Kriteria Penilaian Variabel

\begin{tabular}{|c|c|c|c|c|}
\hline \multirow[t]{2}{*}{ No. } & \multirow{2}{*}{$\begin{array}{l}\text { Kode } \\
\text { Pertanyaan }\end{array}$} & \multirow{2}{*}{$\begin{array}{l}\text { Faktor } \\
\text { Risiko }\end{array}$} & \multicolumn{2}{|c|}{$\begin{array}{l}\text { Kriteria Penilaian } \\
\text { Variabel }\end{array}$} \\
\hline & & & Mean & Keterangan \\
\hline 1 & P1 & \multirow{4}{*}{$\begin{array}{l}\text { Faktor } \\
\text { Keuangan }\end{array}$} & 21.53 & Rendah \\
\hline 2 & $\mathrm{P} 2$ & & 52.35 & Tinggi \\
\hline 3 & P3 & & 47.65 & Sedang \\
\hline 4 & P7 & & 47.65 & Sedang \\
\hline 5 & P10 & \multirow{3}{*}{$\begin{array}{l}\text { Faktor } \\
\text { Penjualan / } \\
\text { Pemasaran }\end{array}$} & 46.47 & Sedang \\
\hline 6 & P11 & & 32.88 & Sedang \\
\hline 7 & P12 & & 57.06 & Tinggi \\
\hline 8 & P13 & \multirow{4}{*}{$\begin{array}{l}\text { Faktor } \\
\text { Pelaksanaan } \\
\text { Lapangan }\end{array}$} & 15.91 & Rendah \\
\hline 9 & P14 & & 42.94 & Sedang \\
\hline 10 & P15 & & 35.24 & Sedang \\
\hline 11 & P16 & & 31.97 & Sedang \\
\hline 12 & P17 & \multirow{3}{*}{$\begin{array}{l}\text { Faktor } \\
\text { Tenaga } \\
\text { Kerja }\end{array}$} & 42.94 & Sedang \\
\hline 13 & P18 & & 18.00 & Rendah \\
\hline 14 & P19 & & 15.00 & Rendah \\
\hline 15 & $\mathrm{P} 20$ & & 51.18 & Tinggi \\
\hline
\end{tabular}




\begin{tabular}{|c|c|c|c|c|}
\hline 16 & $\mathrm{P} 21$ & \multirow{2}{*}{$\begin{array}{l}\text { Faktor } \\
\text { Material }\end{array}$} & 50.00 & Tinggi \\
\hline 17 & $\mathrm{P} 22$ & & 15.00 & Rendah \\
\hline 18 & $\mathrm{P} 23$ & \multirow{2}{*}{$\begin{array}{l}\text { Faktor } \\
\text { Politik \& } \\
\text { Legalitas }\end{array}$} & 16.18 & Rendah \\
\hline 19 & $\mathrm{P} 24$ & & 17.35 & Rendah \\
\hline 20 & $\mathrm{P} 25$ & \multirow{3}{*}{$\begin{array}{l}\text { Faktor } \\
\text { Alam }\end{array}$} & 47.65 & Sedang \\
\hline 21 & P26 & & 51.18 & Tinggi \\
\hline 22 & $\mathrm{P} 27$ & & 41.76 & Sedang \\
\hline \multicolumn{3}{|c|}{ Mean Total } & 34.63 & Sedang \\
\hline
\end{tabular}

Berdasarkan Tabel 3.8, dapat diketahui bahwa variabel risiko yang berdampak dalam katagori tinggi berdasarkan analisis deskriptif pada pengembang perumahan yang membangun perumahan pada masa pandemi covid-19 di Kota Banda Aceh dan Kabupaten Aceh Besar yang menjadi factor risiko diminan merupakan variabel No. 2 (Calon pembeli menunda pembelian rumah), No.12 (minat pembeli Kurang), No. 20 (Keterlambatan pengiriman material). Hasil perhitumgan mean total frekuensi terjadinya variabel risiko termasuk dalam kriteria penilaian "Sedang" dengan nilai sebesar 34.66, artinya frekuensi terjadinya risiko 31-50\%.

\subsubsection{Analisis Frekuensi Indeks}

Analisis ini digunakan untuk menunjukan indeks frekuensi dan peringkat bagi setiap variabel risiko dan dampak yang ditimbulkan berdasarkan kerugian biaya, kerugian waktu, dan menurunnya mutu. Dalam analisis ini, setiap variabel risiko mempunyai nilai frekuensi berdasarkan jumlah responden yang menjawab pertanyaan yang sama dengan jawaban yang sama. Hasil rekapitulasi dapat dilihat pada table dibawah ini.

Tabel 3.9 Rekap hasil perhitungan frekuensi indek

\begin{tabular}{|c|c|c|c|c|}
\hline No & Kode & Dampak & FI & Ket. \\
\hline 1 & $\mathrm{P} 2$ & \multirow{4}{*}{$\begin{array}{l}\text { (Biaya) } \\
\text { Faktor Keuangan }\end{array}$} & 0.64 & Tinggi \\
\hline 2 & P3 & & 0.60 & Tinggi \\
\hline 3 & P7 & & 0.60 & Tinggi \\
\hline 4 & P1 & & 0.36 & Sedang \\
\hline 5 & P12 & \multirow{3}{*}{$\begin{array}{l}\text { (Biaya) } \\
\text { Faktor Penjualan }\end{array}$} & 0.68 & Tinggi \\
\hline 6 & P10 & & 0.59 & Tinggi \\
\hline 7 & P11 & & 0.47 & Sedang \\
\hline 8 & P14 & \multirow{4}{*}{$\begin{array}{l}\text { (Waktu) } \\
\text { Faktor Teknis } \\
\text { Lapangan }\end{array}$} & 0.56 & Tinggi \\
\hline 9 & P15 & & 0.49 & Sedang \\
\hline 10 & P16 & & 0.46 & Sedang \\
\hline 11 & P13 & & 0.31 & Sedang \\
\hline 12 & P17 & \multirow{3}{*}{$\begin{array}{l}\text { (Mutu) Faktor } \\
\text { Tenaga Kerja }\end{array}$} & 0.56 & Tinggi \\
\hline 13 & P18 & & 0.33 & Sedang \\
\hline 14 & P19 & & 0.30 & Rendah \\
\hline 15 & P20 & \multirow{3}{*}{$\begin{array}{l}\text { (Waktu) } \\
\text { Faktor Material }\end{array}$} & 0.63 & Tinggi \\
\hline 16 & P21 & & 0.62 & Tinggi \\
\hline 17 & P22 & & 0.30 & Rendah \\
\hline 18 & $\mathrm{P} 24$ & \multirow{2}{*}{$\begin{array}{l}\text { (Waktu) } \\
\text { Politik \& } \\
\text { Legalitas }\end{array}$} & 0.32 & Sedang \\
\hline 19 & $\mathrm{P} 23$ & & 0.31 & Sedang \\
\hline 20 & P26 & \multirow{2}{*}{$\begin{array}{l}\text { (Waktu) } \\
\text { Faktor Alam }\end{array}$} & 0.63 & Tinggi \\
\hline 21 & $\mathrm{P} 25$ & & 0.60 & Tinggi \\
\hline
\end{tabular}

Berdasarkan tabel 7, dapat diketahui bahwa variabel risiko yang paling dominan berdampak pada pengembang perumahan di Kota Banda Aceh dan Kabupaten Aceh Besar pada masa pandemi Covid-19 dengan kode P12 yaitu "Minat Pembeli Kurang" dengan nilai frekuensi indeks sebesar 0.68. Sedangkan variabel yang tidak berdampak besar oleh pengembang perumahan merupakan variabel P6 "Upah Tenaga Kerja Naik' dengan nilai frekuensi indeks sebesar 0.29.

\subsection{Pembahasan}

Pengumpulan data dilakukan dengan menggunakan metode identifikasi risiko dan wawancara terhadap pengembang perumahan, penentuan narasumber dilakukan terhadap pengembang perumahan yang tergabung dalam asosiasi REI dan APERSI yang sedang mengerjakan pembangunan perumahan pada masa pandemi covid-19 di Kota Banda Aceh dan Kabupaten Aceh Besar.

Berdasarkan hasil identifikasi variabel risiko dari hasil wawancara terhadap 4 orang responden dengan masing-masing perusahaan pengembang perumahan yang berbeda didapatkan hasil berupa 25 variabel risiko teridentifikasi dari 35 pertanyaan yang diajukan dan berdampak terhadap kerugian biaya, kerugian waktu, dan menurunnya mutu sangat dirasakan selama proses pembangunan perumahan pada masa pandemi covid-19.

Strategi yang menjadi langkah tindakan untuk meminimalisir dampak risiko yang dialami pengembang perumahan terhadap kerugian biaya, kerugian waktu, dan menurunnya mutu untuk melancarkan proses pembangunan meliputi tindakan peningkatan terhadap proses pemasaran / penjualan rumah diantaranya meningkatkan proses pengiklanan rumah yang ditawarkan serta fasilitas yang didapatkan terhadap rumah yang ditawarkan. Berdasarkan hasil risiko yang telah teridentifikasi, peneliti merancang kuesioner yang ditujukan kepada 20 orang responden dengan masing-masing perusahaan yang berbeda untuk melakukan wawancara dan kuisioner. Hasil pengumpulan data kuesioner akan diolah dengan menggunakan analisis statistika untuk dilakukan pengujian variabel risiko dengan melakukan uji validitas dan uji reliabilitas kuesioner yang disebarkan. Penyebaran kuisioner dilakukan 
dengan menggunakan dua tahap, dimana pada tahap pertama jumlah responden yang diwawancarai berjumlah 10 orang. Pada tahap ini didapatkan hasil dari pengolahan data dengan melakukan pengujian validitas didapatkan sebanyak 5 variabel risiko yaitu pertanyaan dengan kode P4, P5, P6, P8, dan P9 yang tidak valid, maka variabel tersebut dieliminasi. Selanjutnya setelah pengujian pada tahap 1 selesai dilanjutkan dengan penyebaran kuisioner tahap 2 dengan total keseluruhan responden berjumlah 20 orang dengan masing-masing perusahaan yang berbeda, maka hasil pengolahan data dengan melakukan pengujian validitas didapatkan hasil bahwa keseluruhan variabel risiko dinyatakan valid, sehingga dapat dilanjutkan pengujian reliabilitas. Hasil dari pengujian reliabilitas didapatkan seluruh variabel resiko memiliki nilai C-Alpha hitung > nilai $\alpha$, maka kuesioner dapat dikatakan sangat reliable. Hasil anlisis menunjukan bahwa variabel risiko yang berada di peringkat pertama atau yang paling dominan terjadi pada pengembang perumahan adalah variabel P12 (Minat pembeli kurang) dengan nilai frekuensi indeks sebesar 0.68.

Kesimpulan dari hasil analisis dapat disimpulkan bahwa masih ada faktor risiko yang mempengaruhi dampak risiko terhadap pengembang perumahan dalam melakukan kegiatan pembangunan perumahan pada masa pandemi covid-19. Dimana pihak pengembang perumahan sulit untuk menjalankan proses penjualan produk rumah yang ditawarkan kepada konsumen, serta dampak yang dialami dari menurunya penjualan rumah berpengaruh terhadap kerugian biaya dan kerugian waktu oleh pengembang itu sendiri. Salah satu variabel risiko yang memiliki dampak terhadap biaya adalah "Meningkatnya biaya operasiaonal selama pembangunan perumahan". Hal ini dialami oleh pengembang berdasarkan keterlambatan waktu untuk menyelesaikan proses pembangunan rumah. Sedangkan beberapa variabel risiko yang memiliki dampak terhadap waktu adalah "Keterlambatan pengiriman material ke lapangan", dan "Cuaca buruk sehingga pekerjaan melambat seperti sering terjadi hujan sehingga pekerja sering terganggu". Hal ini terjadi di lapangan karena faktor material dan faktor alam.

\section{Kesimpulan dan Saran}

\subsection{Kesimpulan}

Hasil identifikasi risiko menunjukan bahwa pengembang perumahan memiliki permasalahan selama proses pembangunan perumahan, diantaranya dampak yang ditimbulkan selama pandemi covid-19 merupakan kerugian biaya dan kerugian terhadap waktu.

Sedangkan pengujian instrument dilakukan dengan melakukan pengujian validitas dan pengujian reliabilitas. Uji validitas dilakukan bertahap, tahap I dengan jumlah responden 10 orang didapatkan 5 variabel risiko tidak valid yaitu variabel risiko dengan kode pertanyaan $\mathrm{P} 4, \mathrm{P} 5, \mathrm{P} 6$, P8, dan P9 maka variabel tersebut dieliminasi. Sedangkan hasil uji validitas tahap 2 dengan jumlah total responden 20 orang menunjukan seluruh variabel risiko dinyatakan valid. pengujian reliabilitas, semua butir pernyataan kuisioner dinyatakan sangat reliabel.

Hasil Analisis menunjukan variabel dengan tingkat dampak risiko dominan yang dihadapai oleh pengembang perumahan berupa "minat pembeli kurang" merupakan variabel risiko yang mempengaruhi terhadap kerugian biaya pada perusahaan dengan frekuensi kejadian tinggi yang dihadapi oleh pengembang perumahan pada masa pandemi covid-19. Sedangkan variabel dengan tingkat dampak risiko dominan mempengaruhi terhadap kerugian waktu berupa faktor material dan faktor alam, "Keterlambatan pengiriman material ke lapangan", dan "cuaca buruk sehingga pekerjaan melambat seperti sering terjadi hujan sehingga pekerja sering terganggu" merupakan hambatan selama pelaksanaan pekerjaan di lapangan.

\subsection{Saran}

Berdasarkan hasil penelitian ini maka dapat disarankan perlu dilakukan pengkajian risikorisiko apa saja yang akan dihadapi pengembang perumahan selama pembangunan perumahan sehingga dapat menghindari dampak risiko terhadap kerugian biaya, kerugian waktu, dan menurunnya mutu.

\section{Daftar Pustaka}

[1] Yusuf AM, Metode Penilitian: Kuantitatif, Kualitatif dan penilitian Gabungan, Kencana, Jakarta, 2017.

[2] Anonim, Daftar lokasi perumahan (sikumbang.ppdpp.id, diakses 6 Oktober 2020).

[3] Labombang, M.,Manajemen Resiko Dalam Proyek Konstruksi, Jurnal SMARTek, 2011. 
[4] Maharani K. Pengembang tidak lepas tanggung jawab, 2016 (diakses di : www.rumah.com pada 03-Oktober-2020).

[5] Partamihardja Basuki, Persepsi Risiko Pengembang Perumahan di Kabupaten Bayumas, 2014.

[6] Project Management Institute PMBOK guide, A guide to the project management body of knowledge, Sixth edition. | Newtown Square, PA: Project Management Institute, 2017.

[7] Rumimper R, dkk, Analisis Risiko Pada Proyek Konstruksi Perumahan di Kabupaten Minahasa Utara, 2015. 